\title{
The Role of Machine Element Applications (MEA) as Interactive Mobile Learning to Support the Implementation of Distance Learning in Machine Element Course
}

\author{
https://doi.org/10.3991/ijim.v16i05.28997
}

\author{
Riana Nurmalasari ${ }^{1(\bowtie)}$, Marsono ${ }^{1}$, Abd Kadir Mahamad $^{2}$ \\ ${ }^{1}$ State University of Malang, Malang, Indonesia \\ ${ }^{2}$ University Tun Hussein Onn Malaysia, Johor, Malaysia \\ riana.nurmalasari.fteum.ac.id
}

\begin{abstract}
The digital era has accelerated the development of educational media. This enables access to educational activities from any location at any time. Distance education is gaining popularity and flexibility in its implementation. The purpose of this study is to determine the role of MEA applications in machine element learning, specifically in the State University of Malang's D3 Mechanical Engineering Study Program. MEA is an interactive mobile learning platform designed to broaden D3 students' access to sources and learning tools. This is a quantitative descriptive study. The population of this study consisted of 40 students enrolled in D3 Mechanical Engineering at the State University of Malang. The data were gathered through literacy assessments, observations, interviews, and questionnaires. The tool is a questionnaire constructed on the basis of the Likert scale. Instrument testing included validity and reliability checks. The data analysis technique was descriptive analysis. Five conclusions have been drawn as a result of the analysis. First, the MEA application is $78.6 \%$ user-friendly. Second, the MEA application is easy to use for the machine element learning process in $82.1 \%$ of cases. Third, the MEA application assists the machine element learning process by $75 \%$. Fourth, $89.3 \%$ of MEA application technology is suitable for distant education in the machine element course. Fifth, MEA applications improve machine element learning outcomes by $82.1 \%$.
\end{abstract}

Keywords - machine element applications (MEA), interactive, mobile, learning, distance, media

\section{Background}

Science advancements in the twenty-first century, notably in the realm of Information and Communication Technology (ICT), have always had an effect on the educational sector. Without exception, educational media sources [1] [2]. Until now, conventional methods of teaching and learning have been unable to fully engage students' attention [3]. Computer-aided learning (CAL), computer-based training/learning (CBT/L), 
multimedia-based learning (MBL), web-based learning (WBT/L), and research on online learning and e-learning are all examples of computer-based learning models that have evolved in tandem with the advancement of computer technology [4]. All of these phrases pertain to the same fundamental concept: utilizing computer technology as a foundation for multimedia technology in the development of teaching media models.

Based on observations it is known that the incorporation of learning resources into mechanical element learning in the Mechanical Engineering D3 study program feels extremely urgent, as there have been few interactive multimedia learning resources used in the D3 study program thus far, particularly given that the D3 Mechanical Engineering study program was only integrated into Sipejar in the mid-odd semester 2020/2021. As a result, the bulk of the learning processes in the Mechanical Engineering D3 study program continue to be dominated by traditional learning and do not incorporate technology for interactive learning.

It is necessary to use interesting learning media in order to improve the quality of the teaching and learning process, particularly in lectures [5] [6]. Its purpose is to facilitate the visualization and easy transfer of information from the teaching staff to the students. Machine Elements Application is one of the learning media that can be created. This application aims to help students learn independently for the mechanical element course in the D3 Mechanical Engineering study program by providing them with interesting topics and material in a short period of time that is easy to understand.

The Machine Elements Application's objective is to develop multimedia learning aids for learning about machine elements. This application is built around the concept of interactive learning media that can be accessible both online and offline via mobile devices. This is to ensure that students do not feel bored while studying independently on their cellphones/laptops, and that the learning process can take place more flexibly outside of the classroom, at any time.

Until now, based on observation at mechanical engineering D3 study program State University of Malang, no application has been used to support machine element learning, particularly applications that students can use to study independently. Machine Elements Application, created for the machine element course, contains machine element theory and concepts, as well as quizzes for practice on each topic. To make learning easier for students, the Machine Elements Application can be accessed online or offline. This application is available for download from the Google Play Store. Offline use on a computer or laptop, specifically by installing a virtual Android on a laptop.

\section{Methods}

The purpose of this study is to determine the role of MEA applications in machine element learning, specifically in the State University of Malang's D3 Mechanical Engineering Study Program. MEA is an interactive mobile learning platform designed to broaden D3 students' access to sources and learning tools. This is a quantitative descriptive study. The population of this study consisted of 40 students enrolled in D3 Mechanical Engineering at the State University of Malang. The data were gathered through literacy assessments, observations, interviews, and questionnaires. The tool is a questionnaire constructed on the basis of the Likert scale. Instrument testing included validity and reliability checks. The data analysis technique was descriptive analysis. 


\section{$3 \quad$ Results and discussion}

\subsection{The ease of access to MEA application}

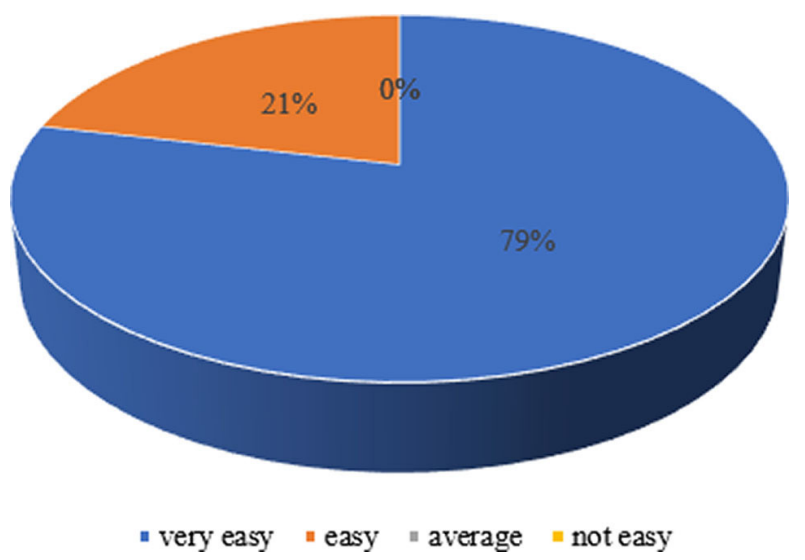

Fig. 1. The ease of access to MEA application

According to the findings of the analysis, the level of ease of access to the MEA application is very high, at 78.6 percent. The MEA application is easy to access because users can find it on the play store, the installation method on a mobile phone is simple, it does not take up a lot of space on the mobile phone, and it can be used offline, compatible with virtual android, and the operating system is easy. Furthermore, the user's age is a major factor in the ease of access to the MEA application. This is due to the fact that the majority of people who use MEA for machine element learning are students between the ages of 18 and 23. This is the generation of millennials, who are very familiar with technology and its applications. As a result, they have very easy access to the MEA application. According to [7] [8], smartphone-based learning applications are very easy to access and use because they are fast, light, and portable. [9] agrees, stating that applications on smartphones are generally simple to access and use.

\subsection{The ease of using the MEA application for the machine element learning process}

According to the analysis results, the level of ease of use of the MEA application is very easy, 82.1 percent. This is due to the fact that the MEA application is extremely simple to use. According to [10], applications built with Android technology are more efficient and effective than those built with other technologies. According to [11], the mobile application is easy for students to operate. The MEA application's features are simple enough to use for learning, both independently and in the classroom during the learning process. Materials and quizzes are among the features of the MEA application. Students can learn machine element material independently and at their own pace at any time and from any location. All of the content in the MEA application is made up of interesting explanations and looks. Students can continue to take quizzes 
after they have studied the material. The available quizzes are chosen at random, so no two students will take the same 100 percent quiz. Furthermore, the quiz can only be taken once. Students who have already taken the quiz will be unable to retake it unless the quiz is reset. Quizzes are also equipped with a timer, so students must ensure that they are truly prepared when taking the quiz in order to achieve the best results. After completing the quiz, students can immediately find out their quiz results at the end of the session.

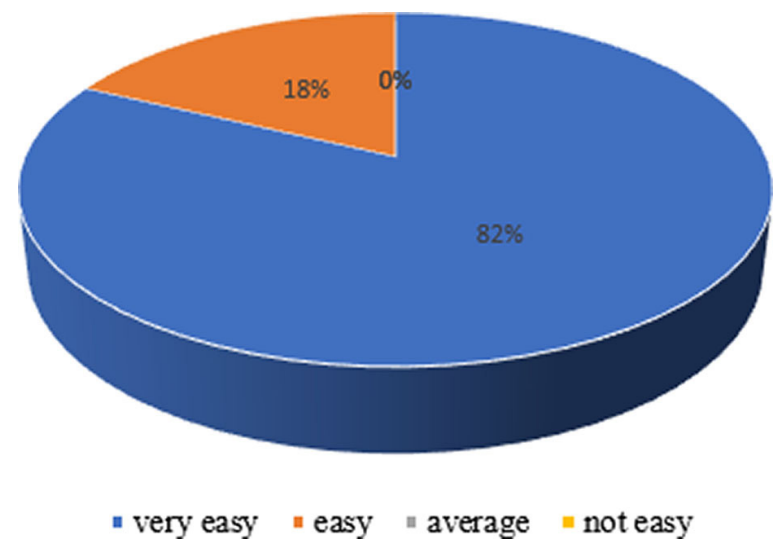

Fig. 2. The ease of using the MEA application for the machine element learning process

\subsection{The role of MEA application in helping the machine element learning process}

According to the findings of the analysis, the MEA application aids the machine element learning process by $75 \%$. There is currently no application used to support the learning of machine element courses, particularly applications that students can use to study independently at the Department of Mechanical Engineering, State University of Malang. The MEA created for the machine element course includes machine element theory and concepts, as well as quizzes for practice on each topic. The MEA that was created is for the creation of multimedia learning resources for machine element learning. The concept used in the development of this application is an interactive learning media that can be accessed both online and offline using mobile applications. This is intended to ensure that students do not become bored while studying independently on their cellphones/laptops, and that the learning process can be carried out more flexibly anywhere, at any time, rather than just in the classroom. According to [12], e-learning is the use of information and communication technologies to enable access to online learning/teaching resources. Furthermore, according to [13] the android application is quite effective to stimulate student understanding. 


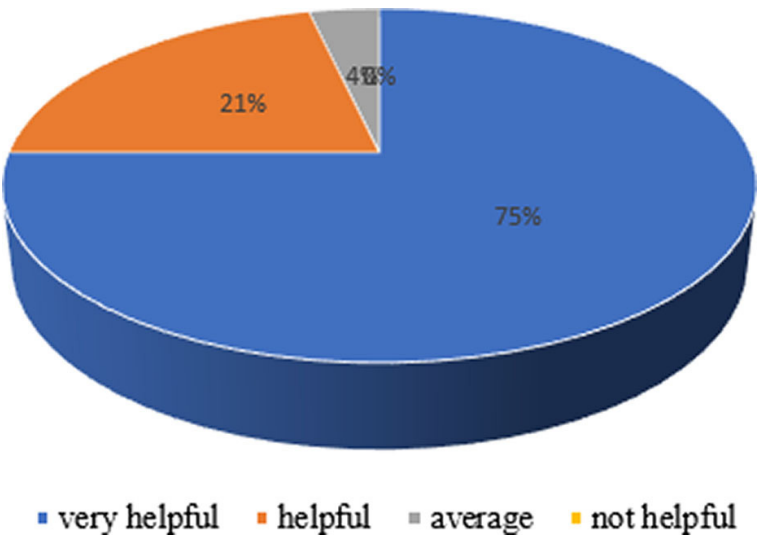

Fig. 3. The role of MEA application in helping the machine element learning process

\subsection{The suitability of MEA application technology for distance learning in the machine element course}

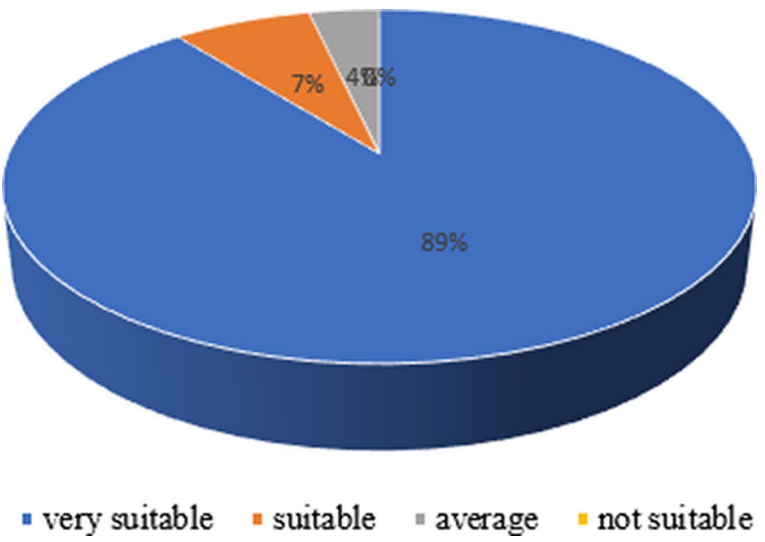

Fig. 4. The suitability of MEA application technology for distance learning in the machine element course

According to the findings of the analysis, the suitability of MEA application technology for distance learning in the machine element course is 89.3 percent. The MEA application was created so that students could access it at any time and from any location. This clearly demonstrates that the MEA application can be used for distance learning either independently or with the guidance of a lecturer. MEA application development for multimedia teaching materials. The concept of multimedia evolves into the integration of multiple media, such as text, graphics, sound, video, and animation, in which students can control the delivery of various multimedia elements [14]. According to Hofstetter, multimedia is the use of computers to create and combine text, audio graphics, moving images (video and animation), and other media by combining 
link tools that allow users to navigate, interact, create, and communicate [15]. According to [16], the goal of multimedia is to present information in a way that is enjoyable, interesting, easy to understand, and clear. Because information is absorbed using as many senses as possible, particularly the ears and eyes, it will be easy to understand. Multimedia is derived from two words: multi, which means more than one, and media, which means a means of communication. Multimedia can be defined as a mode of communication that employs a variety of media. Images, sound, animation, and text are examples of media [17]. Based on the explanation, the MEA application was created to facilitate distance learning while also focusing on the application's attractiveness so that students are more interested and enthusiastic about learning. During the pandemic, the MEA application was used to support machine elements courses at the Department of Mechanical Engineering, State University of Malang.

\subsection{The role of MEA applications to improve machine element learning outcomes}

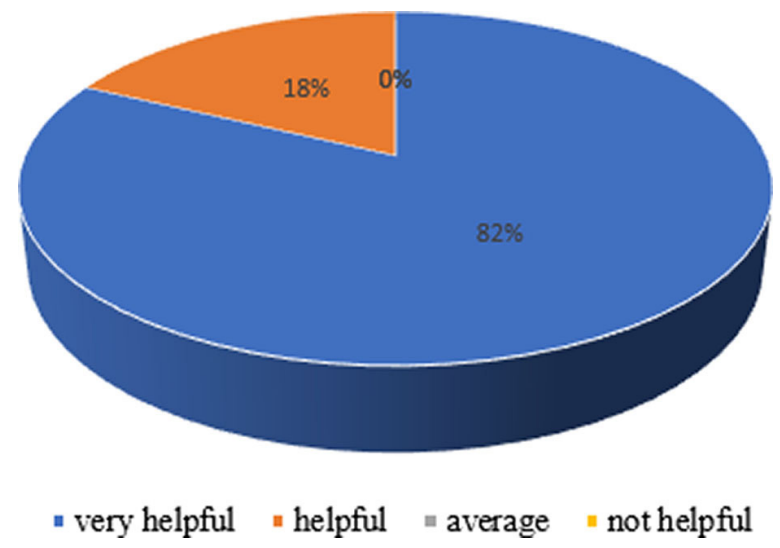

Fig. 5. The role of MEA applications to improve machine element learning outcomes

According to the analysis's findings, MEA is used to increase learning outcomes in machine elements courses by $82.1 \%$. Students can study independently during lectures and in their free time when the MEA application is used in the machine element course. In this scenario, students learn through the use of applications in blended learning. [18] research demonstrates a considerable boost in students' learning results when blended learning is used in conjunction with applications. Additionally, the MEA application's look and operation are fairly straightforward, making it easy for students to learn. This is one of the aspects that contribute to the MEA application's improved learning outcomes. [19] asserts that integrating technology into the learning process in order to accomplish learning objectives is critical in today's society. This perspective is consistent with [20] [21] research findings, which indicate that learning applications have an effect on students' perception, focus, and capacity to use smartphones for e-learning. Additionally, educators have a critical role in enhancing learning outcomes [22]. 


\section{Conclusion}

MEA is one of the applications designed to aid in the learning of machine elements. It is envisaged that the MEA applications will enable learning processes and activities to function more efficiently and effectively, particularly during this pandemic situation. Five conclusions were drawn as a result of the research. First, the MEA application is $78.6 \%$ user-friendly. Second, the MEA application is easy to use for the machine element learning process in $82.1 \%$ of cases. Third, the MEA application assists the machine element learning process by $75 \%$. Fourth, $89.3 \%$ of MEA application technology is suitable for distant education in the machine element course. Fifth, MEA applications improve machine element learning outcomes by $82.1 \%$.

\section{$5 \quad$ Acknowledgment}

We would like to express our gratitude to everyone who contributed to the completion of this research. To the State University of Malang, LP2M UM, and LP3 UM in particular.

\section{References}

[1] Wang, Y. S. et al. (2007). Determinants of User Acceptance of Internet Banking: An Empirical Study. International Journal of Service Industry Management, 14, 501-519. https://doi. org/10.1108/09564230310500192

[2] Usman. (2017). Dynamics of Information Technology-Based Learning in Higher Education Institutions. Jurnalisa, 3(1), 61-75. https://doi.org/10.24252/jurnalisa.v3i1.3065

[3] Sudjana, N. (2001). Assessment of the Results of the Teaching and Learning Process. Bandung: Remaja.

[4] Sinsuw, Alicia A. E \& Sambul, Alwin M. (2017). Information Technology-Based Learning Media Development Training for Middle School Teachers. Journal of Electrical and Computer, 6(3), 105-110.

[5] Nursamsu \& Kusnafizal, Teuku. (2017). Utilization of ICT Learning Media as Student Learning Activities at SMPN Aceh Tamiang. Journal of Science and Science Learning, 1(2), 165-170. https://doi.org/10.24815/jipi.v1i2.9691

[6] Danim, S. (2011). Teacher Professional Development from Pre-service, Induction, to Civilian Professional. Jakarta: Prenada Media.

[7] Zatulifa, Muzayyana; Riswandi; Fitriawan, Helmi; \& Akla. (2018). Application Based Android as a Development of English Learning Media. Journal of Research \& Method in Education, 4(3), 66-72.

[8] Purnadi et al. (2018). Effectiveness of the Device Network Application Initiative Learning Model Towards the Students' Information and Communication Technology Skills. Journal of Vocational Education Studies, 1(1), 1-6. https://doi.org/10.12928/joves.v1i1.586

[9] Mandailina, Vera et al. (2019). Analysis of Usage Level of Android Applications as Learning Media in Indonesian Educational Institutions. International Journal of Education \& Curriculum Application, 2(3), 16-23. https://doi.org/10.31764/ijeca.v2i3.2080 
[10] Pahriah, P \& Khery, Y. (2018). Android-Based Learning Applications on Elements Periodic System Materials for Increasing Student Concept Understanding. Hydrogen Chemistry Educational Journal, 5(1), 24-34. https://doi.org/10.33394/hjkk.v5i1.105

[11] Suhailiezana, A. Shah et al. (2019). Effectiveness of m-Learning Applications for Design and Technology Subject. Journal of Interactive Mobile Technologogies, 13(10), 120-133. https://doi.org/10.3991/ijim.v13i10.11324

[12] Arkorful, Valentina \& Abaidoo, Nelly. (2014). The Role of E-learning, the Advantages and Disadvantages of Its Adoption in Higher Education. International Journal of Education and Research, 2(12), 397-410.

[13] Safitri et al. (2019). The Effectiveness of Android Application as a Student Aid Tool in Understanding Physics Project Assignments. Jurnal Pendidikan IPA Indonesia, 8(4), 512-520. https://doi.org/10.15294/jpii.v8i4.19433

[14] Sunarto, S. (2005). Discussion of Research Results: Development of Interactive Learning Media for Dishes Courses. Inotek Journal, 9(1), 23-28.

[15] Suyanto, M. (2003). Multimedia Tools to Increase Competitive Advantage. Yogyakarta: ANDI.

[16] Pribadi, Benny A. (2004). Availability and Utilization of Media and Learning Technology in Higher Education. Educational Journal, 5(2), 146-148.

[17] Chandra, H. (2002). Create Your Own Professional Animation with 3ds max 4.2. Jakarta: Elex Media Komputindo.

[18] Kintu, Mugenyi Justice et al. (2017). Blended Learning Effectiveness: The Relationship Between Student Characteristics, Design Features and Outcomes. International Journal of Educational Technology in Higher Education, 14(7), 1-20. https://doi.org/10.1186/ s41239-017-0043-4

[19] Paolini, Allison. (2015). Enhancing Teaching Effectiveness and Student Learning Outcomes. The Journal of Effective Teaching, 15(1), 20-33.

[20] El-Sofany, Hosam F. (2020). The Effectiveness of Using Mobile Learning Techniques to Improve Learning Outcomes in Higher Education. International Journal of Interactive Mobile Technologies, 14(8), 4-18. https://doi.org/10.3991/ijim.v14i08.13125

[21] Setiawan, M. Rizky \& Wiedarti, Pangesti. (2020). The Effectiveness of Quizlet Application Towards Students' Motivation in Learning Vocabulary. Studies in English Language and Education, 7(1), 83-95. https://doi.org/10.24815/siele.v7i1.15359

[22] Nurmalasari, Riana; Puspitasari, Poppy; Mardji; Hartiningtyas, Lativa; Suswanto, Hary. (2016). The Role of Sarjana Mengajar's Teachers for Student's Outcomes on Vocational High School. AIP Conference Proceeding, 1778, pp 1-3. https://doi.org/10.1063/1.4965776

\section{$7 \quad$ Authors}

Riana Nurmalasari is young lecturer at the Malang State University, Indonesia. Active in writing scientific papers, researching, and developing learning technology. She often conduct international collaborative research. (Email: riana.nurmalasari.ft@, um.ac.id).

Marsono is a lecturer who is involved in international cooperation, he is also one of the innovators in the field of education, manufactur, more than 10 copyrights resulting from research collaborations (Email: marsono.ft@um.ac.id)

Abd Kadir Mahamad is an active associate professor at Tun Hussein Onn University Malaysia, Johor, Malaysia. (Email: kadir@uthm.edu.my).

Article submitted 2021-12-17. Resubmitted 2022-01-18. Final acceptance 2022-01-19. Final version published as submitted by the authors. 